\title{
A New Diagnostic Test for Psychogenic Amenorrhea
}

\section{Kohachiro KOGA, Yasushi OKAMURA and Masahiro KITAZIMA}

Department of Gynecology and Obstetrics, Faculty of Medicine, Kyushu University

The clinical use of SU 4885 (2-methyl-1, 2-bis-(3-pyridyl)-1-propane) furnishes a new diagnostic test for the indirect evaluation of AGTH pituitary function, provided the adrenal can be assumed to be normal. An increment of 17-ketosteroids is the final result of the enzymic block artificially produced by administration of SU 4885. This is the normal response in a normal pituitary adrenal axis.

On the other hand, if a pituitary lesion exists with anatomic destruction of the pituitary, the increment in ACTH levels following administration of this drug is absent or diminished when compared with that in a normal individual. The urinary excretion of 17-ketosteroids is only slightly elevated or not elevated at all during the test performance. Amenorrhea due to psychogenic or neurogenic factors is frequently associated with laboratory findings indicative of total pituitary insufficiency and is in no way different from those associated with destructive pituitary lesions.

The SU 4885 test for pituitary reserve function might serve as a diagnostic aid under these circumstances. Three patients having amenorrhea of undetermined central etiology were given a test for pituitary reserve function using SU 4885.

Case reports :

(1) Y.K. This patient is a 21-year-old unmarried woman complaining of primary amenorrhea. Since September 1962, she had been treated by hormone (once a week, total 15 times), but she had not menstruated. The family history was noncontributory; there are 5 brothers and sisters with no history of amenorrhea or menstrual irregularities. As for her past history, she suffered from chicken-pox at the age of 3 years. The physical examination showed a normally developed, rather poorly nourished thin woman weighing $44 \mathrm{Kg}, 160 \mathrm{~cm}$, with normal axillary and minimal pubic hair, slight hirsutism of the limbs and no facial acne. The breasts were poorly developed. The pelvic examination showed hypoplastic external genitals. The uterus was "small. The x-ray showed a normal sella. The protein-bound iodine was normal (6.0 mg per dl.). Basal temperature records were monophasic.

(2) M.H. This patient is a 34-year-old unmarried woman complaining of primary amenorrhea. The family history was noncontributory in that there are 4 brothers and sisters with no history of amenorrhea or menstrual irregularities. As for her past history, she suffered from idiopathic thrombopenic purpura and was in the hospital under treatment. The physical examination showed a hypoplastic woman weighing $33.7 \mathrm{Kg}, 136 \mathrm{~cm}$, with no pubic hair and minimal hair on other parts, and no acne. The breasts were poorly developed. On pelvic examination, the external genitals, vagina and 
uterus were hypoplastic. The x-ray showed a normal sella turcica. The protein -bound iodine was normal. Basal temperature records were monophasic.

(3) K.N. This patient was a 21-year-old unmarried woman whose major complaint was secondary amenorrhea. The family history was noncontributory. Her past history was insignficant. Since she had trouble with her marriage on May, 1963, she has been becoming amenorrhea. The physical examination showed a normally developed, moderately nourished woman weighing $46.5 \mathrm{Kg}, 154 \mathrm{~cm}$, without hirsutism except for slight hirsutism on the lower limbs and with scarce facial acne. The breasts were moderately developed. On pelvic examination the external genitals were normal, the uterus was anteverted, normal in size. The total urinary 17 -ketosteroids were $6.4 \mathrm{mg}$. per 24 hours and the protein-bound iodine was high; $8.5 \mathrm{mg}$. per dl. Basal temperature records were monophasic.

Methods and results of experiments:

A SU 4885 test was performed $750 \mathrm{mg}$. every 6 hours during 24 hours.

Several methods have been reported for the determination of total urinary 17-ketosteroids. Of these, the Drekter method was chosen, which made it possible to determine simply and rapidly with a small amount of urine.

The basic steps of the modified procedure are as followed: Twenty $\mathrm{ml}$ of the 24hour urine sample in a $125 \mathrm{ml}$ Erlenmeyer flask is added $0.4 \mathrm{ml}$ of diluted formaldehyde solution (formalin, 40 per cent, diluted 1 to 5 with water), placed $3 \mathrm{ml}$ of concentrated $\mathrm{HCl}$ and stopper the flask with a Pyrex flathead stopper. Heat the flask in a water bath at $80^{\circ} \mathrm{C}$ for 10 minutes, cool transfer $10 \mathrm{ml}$ of the hydrolysate to a $125 \mathrm{ml}$ separatory funnel. Add $40 \mathrm{ml}$ ether and shake the funel for 30 seconds. Remove the urine. Wash the ether once with $20 \mathrm{ml}$ of 10 per cent $\mathrm{NaOH}$ and once with $20 \mathrm{ml}$ of distilled water; shake for 10 seconds with each wash. Remove $10 \mathrm{ml}$ of ether, evaporate the $10 \mathrm{ml}$, and assay by means of the Zimmermann reaction. Remove two samples of $10 \mathrm{ml}$ of ether, evaporate each one. In my determinations, the Zimmermann reaction was performed as follows: Add $0.4 \mathrm{ml}$ absolute alcohol, $0.4 \mathrm{ml}$ of the m-dinitrobensene solution, and $0.6 \mathrm{ml}$ of the $5 \mathrm{~N} \mathrm{KOH}$ solution to the dried extract. Keep the solution in the dark in a water bath whose temperature is $27^{\circ} \mathrm{C}$ for 60 minutes. After 60 minutes dilute the solution with $2 \mathrm{ml}$ of diluent; the diluent consists of three parts of absolute alcohol to one-part of water. Read the diluted solution in a photoelectric spectrophotometer (Hitachi, Ltd.).

The results, seen in Table 1 were obtained. Patients No. 1 and 2 had a decrease, but patient No. 3 had a marked increase in 17-ketosteroids excretion following the administration of SU 4885.

The latter indicated that the pituitary was able to produce increased amounts of ACTH. On the basis of this finding it was assumed that (3) patient was suffering from of a psychogenic form of central amenorrhea rather than a true pituitary necrosis. 


\section{心因性 無月経の新しい鑑別法}

$\begin{array}{cccc}\text { 九州大学医学部産婦人科学教室 } & & \\ \text { 古 } & \text { 賀 康 } & \text { 八 } & \text { 郎 } \\ \text { 岡 } & \text { 村 } & & \text { 靖 } \\ \text { 北 } & \text { 島 } & \text { 正 } & \text { 大 }\end{array}$

(昭和39年 2 月 8 日受付)

緒 言

月経が感情の動摇によつて，鋭敏に影響を受けるととは㞗々認められる事象であり，強い精神的ストレス によつて無月経の状態を惹起するととも少くない．

無月経患者を診断する場合に，果して，精神的因子によるものか，あるいは，下垂体汇器質的病変がある ためのものかを鑑別するてとは臨床上重要である．

そてで, Emanuel, R.W. (1956), Rey \& Nicholson-Bailey (1957), および, Teter, J. (1959) らによつ て，乙の鑑別法を見出す試みがなされて来たが，いずれも成功するに至らなかつた。

とてろが，1962年，Johns Hopkins 大学産婦人科学教室の Jones \& Acosta ${ }^{1}$ が SU 4885 test を用いて鑑 別出来ると報じている.

従つて，私たちは，下記のような臨床像をもつ無月経患者 3 名を選び，SU 4885 負荷を行い，投与前，中， および，後の尿中総 17-KS の推移から興味ある成績を得たので報告する.

症例

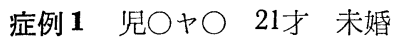

主訴 : 原発性無月経

1962年 9 月以来，hormone 治療を週 1 回，計15回受けたが，出血しなかつた。

家族歴 : 特記所見はない. 5 人の兄弟姉妹がる。姉妹に異常はない.

既往疾患：3才の時，水痘にかかつた。

全身所見：発育は正常だが，稍々栄養が悪い，身長 $160 \mathrm{~cm}$ ，体重 $44 \mathrm{~kg}$ でやせている，腋毛は正常だが，恥

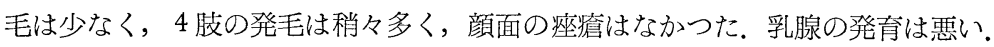

内診所見：外陰に発育不全があり，子宮は小さい．

X線撮影依るトルコ鞍の大きさは正常. P.B.I. は， $6.0 \mathrm{mg} / \mathrm{dl}$. (正常). B.B.T. は 1 相性.

症例 2 平○峰○ 34才 未婚

主訴 : 原発性無月経と外陰の無毛

家族歴：特記所見はない，4人の兄弟，姉妹がいる，月経異常のある者はいない，

既往歴：異常はない，

1963年11月特発性血小板減少性紫斑病で, 現在入院治療中.

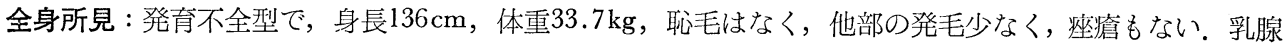
の発育も悪い.

内診所見 : 外陰, 堙, 子宮共に発育不全がある。

X線撮影によるトルコ鞍の大きさは正常. P.B.I. も正常. B.B.T. は 1 相性.

症例 3 中门圭○ 21 才婚 
主訴: 続発性無月経

家族歴 : 特記所見はない.

既往歴：異常はない.

1963年 5 月に結婚問題で trouble が起つてから無月経となつた.

全身所見: 発育は正常で, 栄養は中等度, 身長 $154 \mathrm{~cm}$, 体重 $46.5 \mathrm{~kg}$, 下肢に稍々発毛が多い点を除き, 発 毛は異常がない, 痤瘡は時々発生する。乳腺の発育は中等度.

内診所見 : 外陰は異常なく, 子宮は前傾で, 正常大.

P.B.I. は, $8.5 \mathrm{mg} /$ dl. で高値を示す. B.B.T. は 1 相性.

\section{実験方法および成績}

SU 4885 (CIBA PRODUCTS LTD) の投与方法： 1 回に $750 \mathrm{mg} 6$ 時間每， 1 日 4 回，計 1 日量 $3 \mathrm{~g}$ 投 与した。因みに，SU 4885 の構造は 2-methyl-1, 2-bis-(3-pyridyl)-1-propane である.

尿中 17-KS 測定 : formalin 添加による Drekter 変法 ${ }^{2}$ を次のように行つた.

24 時間尿 $20 \mathrm{ml}$ 亿, 稀釈 formaldehyde 溶液 ( $40 \%$ formalin 1 亿対し水 5 の割合) $0.4 \mathrm{ml}$ と濃塩酸 $3 \mathrm{ml}$ を 加え, $80^{\circ} \mathrm{C}$ の温浴中で, 10 分間加熱する. 次いで泠却し，その中の $10 \mathrm{ml}$ に $40 \mathrm{ml}$ の ether を加え，30秒振湯 してから尿層を捨てる.

ether 首に $10 \% \mathrm{NaOH} 20 \mathrm{ml}$ 老加えて 振盪洗涤し, ついで, 蒸留水 $20 \mathrm{ml}$ で振盪洗桬する. その ether 層から $10 \mathrm{ml}$ 採り，乾固. Zimmermann 反応を次のよう行う.

無水 ethanol $0.4 \mathrm{ml}, \mathrm{m}$-dinitrobenzene 溶液 $0.4 \mathrm{ml}$ および $5 \mathrm{~N} \mathrm{KOH}$ 溶液 $0.6 \mathrm{ml}$ を上記の乾固抽出物に加 える. $27^{\circ} \mathrm{C}$ の温浴に60分間遮光して放置してから ethanol 水溶液 (無水 ethanol $3:$ 蒸溜水 1 の比率) $2 \mathrm{ml}$ を加えて比色する (Hitachi 光電比色計).

その成績を表示すると Table 1. の如くであり，SU 4885 投与による 17-KS 排泄は，症例 1，2では減 少し, 症例 3 では著明に增加した。

後者においては，下垂体が，AGTH を充分分泌し得る予備能があることを示している.

Table 1. Results of SU 4885 administration to 3 patients with amenorrhea

\begin{tabular}{c|c|c|c}
\hline \hline \multirow{2}{*}{ Patient } & \multicolumn{3}{|c}{ 17-Ketosteroids (mg./24 hours) } \\
\cline { 2 - 4 } & Control values & (750mg. every 6 hours/24 hours) & 24 hours after SU 4885 \\
\hline \hline 1 & 3.6 & 2.3 & 3.6 \\
2 & 2.3 & 1.2 & 3.7 \\
3 & 6.4 & 7.0 & 9.8 \\
\hline
\end{tabular}

(Koga, K., et al., 1964)

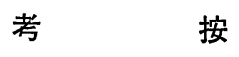

副腎の $11 \beta$-hydroxylase 酵素の特異的なブロック剂としての SU 4885 の発見，および，その臨床的応用 そついて, Liddle らにより初めて記述され, SU 4885 の作用機序については, 専ら, 11/-hydroxylase 活 性の阻害にあると考えられて来た。

とてろが, 最近, Grifiths $(1963)^{33}$ は golden hamster の副腎を用いての実験により，19-hydaoxylase 活

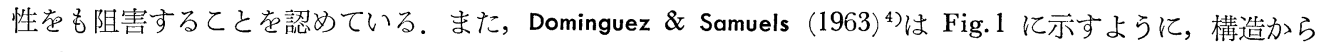
corticosteroid の側鎖と Metopirone（すなわち，SU 4885）との間に幾分の類似性があり， polar pyridyl ring で corticosterone や cortisol の hydroxyl の部位を置換するためであると推論している.

近年，とみに，心身相関の問題が重視され，間脳一下垂体一卵巣・副腎系の上位に存在する大脳皮質が注 
Fig. 1. Similar possible steric orientation of Metopirone and groups at $\mathrm{C}-17$ of the cortical steroids. (Dominguez \& Samuels, 1963)
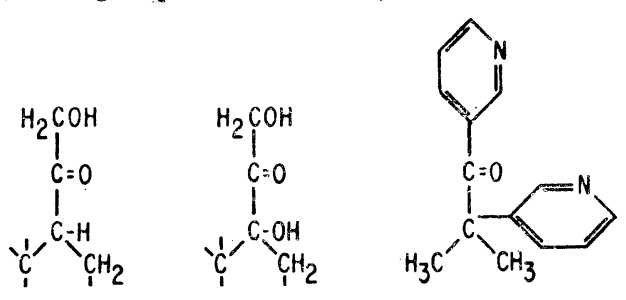

CORTICOSTERONE CORTISOL

\section{目されるに至つた。}

すなわち, Davis \& Fugo $(1961)^{5}$ が示して いるように (Fig.2参照)，大脳皮質から間脳 の neurosecretory cells への精神的な impulse が間脳 $\rightarrow$ 下垂体 $\rightarrow$ 性腺・副腎系に鋭敏 に影響を与えるととを考慮しなければならな い.

症例 3 は結婚問題についての精神的 sheck がこの系に強い影響を与えたために，無月経 を米したものである.

Fig.2. Diagram illustrating the cerebral, hypothalamic, pituitary and ovarian interrelationships of the menstrual cycle (Davis \& Fugo, 1961)

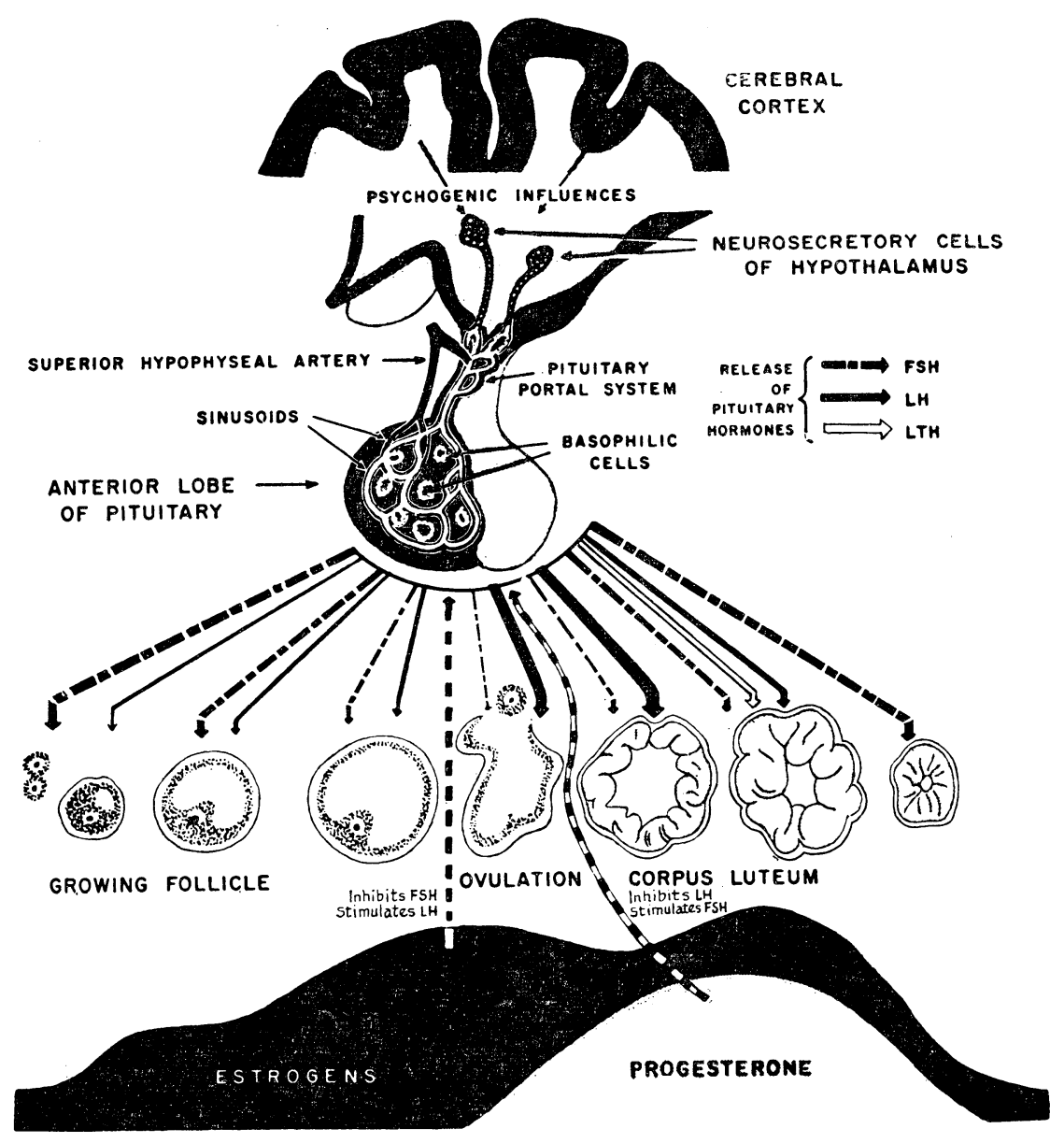




\section{結語}

無月経患者 3 名に SU 4885 投与を行い，その中，原発性無月経 2 例は 17-KS 分泌の減少を来たし，他 方，精神的ストレスが加わつて無月経になつた続発性無月経 1 例では 17-KS 分泌の增加を認めた。すなお ち，前者においては下垂体に器質的病変が存するてとを，後者においてはそれがないてとを示唆しており， 無月経の治療方針を立てる上の指標となる。

$$
\text { 文献 }
$$

1) JONES, G.E.S. \& AGOSTA, A.A. : Am. J. Obst. \& Gynec., 84 : 701, (1962). 2) OKAMURA, Y. : Kyushu J. Med. Sci., 11 : 81, (1960). 3) GRIFFITHS, K. : J. Endocrin., $26: 445$, (1963). 4) DOMiNGUEZ, D.V. \& SAMUELS, L.T. : Endocrinology, $73: 304,(1963) . \quad$ 5) DAVIS, M.E. \& FUGO, N.W. : Med. Clin. North Amer., 45 : 3, (1961). 